\title{
ON THE WESTERN FRINGE OF BABOON DISTRIBUTION: MITOCHONDRIAL D-LOOP DIVERSITY OF GUINEA BABOONS (PAPIO PAPIO DESMAREST, 1820) (Primates: Cercopithecidae) in CoAstal Guinea-Bissau, WESTERN AFRICA
}

\author{
Maria J. Ferreira da Silva ${ }^{* 1,2}$, Catarina Casanova ${ }^{2,3,4,5}$ \& Raquel Godinho ${ }^{1}$ \\ ${ }^{1} \mathrm{CIBIO} /$ InBio, Centro de Investigação em Biodiversidade e Recursos Genéticos, Universidade do Porto, Campus Agrário \\ de Vairão, 4485-661 Vairão, Portugal. \\ ${ }^{2}$ APP, Associação Portuguesa de Primatologia, Av. Berna, 26-C, 1069-061 Lisboa, Portugal \\ ${ }^{3}$ CAAP, Centro de Administração e Políticas Públicas, Instituto Superior de Ciências Políticas e Sociais da Universidade \\ Técnica de Lisboa, Pólo Universitário do Alto da Ajuda, R. Almerindo Lessa, 1300-663 Lisboa, Portugal \\ ${ }^{4}$ Department of Anthropology, Instituto Superior de Ciências Sociais e Políticas (ISCSP) da Universidade Técnica de \\ Lisboa, Pólo Universitário do Alto da Ajuda, R. Almerindo Lessa, 1300-663 Lisboa, Portugal \\ ${ }^{5}$ CESAM, Centre for Environmental and Marine Studies, Lisbon Group, Portugal \\ ${ }^{1}$ ferreiradasilvamj@cf.ac.uk (* corresponding author), ${ }^{2}$ ccasanova@iscsp.utl.pt, ${ }^{3}$ rgodinho@cibio.up.pt
}

\begin{abstract}
Like many primate species in West Africa, habitat loss and intensive hunting are threatening the poorly studied Guinea Baboon (Papio papio). These factors contributed to a significant population contraction during the last 30 years. Our study presents genetic diversity estimates for the Guinea Baboon based on a 391 base pair fragment of the mitochondrial DNA D-loop hypervariable region I. We used non-invasively collected genetic samples from two locations in Guinea-Bissau: Cufada Lagoons Natural Park and Cantanhez Forest National Park. Although most sampling was opportunistic, we observed and collected samples from two dames (social units). Among the 25 sequences obtained, we found seven closely related mtDNA haplotypes and one highly different haplotype. The presence of this divergent haplotype suggests a contact area between genetically differentiated populations in Cufada Lagoons Natural Park, or dispersal of individuals. The samples gathered from both regions share two of the most common haplotypes in different frequencies, but also exhibit unique haplotypes. No significant genetic differentiation was found between social units from both regions, possibly due to common ancestral origin or frequent dispersal between sampling locations. The presence of different maternal lineages in the same social unit and a higher percentage of variation within social units suggest historical female-biased dispersal for Guinea-Bissau Baboons. We further compared mitochondrial genetic diversity of Guinea and Hamadryas Baboons. We found lower haplotype, nucleotide and theta diversity for Guinea Baboons, which points to different demographic histories of these species. This work supports the need for additional genetic studies within the full Guinea Baboon range.
\end{abstract}

Keywords: Baboon, dispersal, habitat loss, hunting, Mitochondrial DNA, primates.

DOI: http://dx.doi.org/10.11609/JoTT.o3216.4441-50 | ZooBank: urn:Isid:zoobank.org:pub:389730A6-1E26-4486-A07C-CF62279AD32A

Editor: Dietmar Zinner, German Primate Center, Göttingen, Germany.

Date of publication: 26 June 2013 (online \& print)

Manuscript details: Ms \# 03216 | Received 24 May 2012 | Final received 30 May 2013 | Finally accepted 01 June 2013

Citation: Ferreira da Silva, M.J., C. Casanova \& R. Godinho (2013). On the western fringe of baboon distribution: mitochondrial D-loop diversity of Guinea Baboons (Papio papio Desmarest, 1820) (Primates: Cercopithecidae) in Coastal Guinea-Bissau, western Africa. Journal of Threatened Taxa 5(10): 4441-4450; http://dx.doi. org/10.11609/JoTT.03216.4441-50

Copyright: @ Ferreira da Silva et al. 2013. Creative Commons Attribution 3.0 Unported License. JoTT allows unrestricted use of this article in any medium, reproduction and distribution by providing adequate credit to the authors and the source of publication.

Funding: Funding was provided by $\mathrm{CIBIO} / \mathrm{InBio}$ - Centro de Investigação em Biodiversidade e Recursos Genéticos, Universidade do Porto and by two private companies - Barbosa \& Almeida Glass I - Serviços de Gestão e Investimentos, SA. and Carosi - Cápsulas e Rolhas Sintéticas Lda. R. Godinho work was funded by Portuguese Foundation for Science and Technology (FCT) under a post-doc grant (SFRH/BPD/36021/2007).

Competing Interest: None.

Acknowledgements, Author Contribution and Author Details: See end of this article.

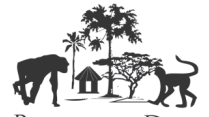

PROJECTO DARI

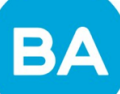

8
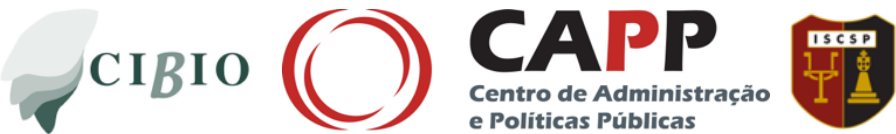

Instituto Superior de Ciências Sociais e Políticas e Politicas Públicas
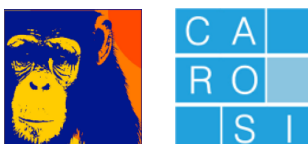

UNIVERSIDADE TÉCNICA DE LISBOA 


\section{INTRODUCTION}

The free-ranging populations of Guinea Baboons (also called Red Baboons, Papio papio Desmarest, 1820) occupy a small distribution area in western Africa (Mauritania, Senegal, Gambia, Mali, Guinea-Bissau, Republic of Guinea and Sierra Leone) when compared with other baboon species (Oates et al. 2008). This poorly studied primate exhibits great ecological plasticity (Galat-Luong et al. 2006; Patzelt et al. 2011) and inhabits a variety of habitats throughout its distribution (GalatLuong et al. 2006).

Guinea Baboons have been listed as Near Threatened and little is known about its populations (IUCN 2013 assessed by Oates et al. 2008) (Image 1). It is acknowledged that certain local or regional populations deserve conservation measures due to their rapid decline in numbers. In several areas in western Africa only fragmented populations persist (Galat et al. 19992000). Excessive habitat degradation by agricultural practices (e.g. slash and burn technique), hunting and persecution by farmers, international trade of juveniles and bushmeat consumption (Wolfheim 1983; Starin 1989; Galat et al. 1999-2000; Oates et al. 2008; Minhós et al. under review) contributed to substantial range contraction during the last 30 years (Oates et al. 2008).

In Guinea-Bissau, wild populations of Guinea Baboons seem to be decreasing at a fast pace (Gippoliti \& Dell'Omo 2003; Casanova \& Sousa 2007; Cá 2008; Costa 2010). In the 1980 s it was still possible to regularly observe troops of Guinea Baboons in most regions of the country and their range extended into the outskirts of Bissau, the capital city. After this date, the baboon conservation status in Guinea-Bissau degraded dramatically. According to the perceptions of local people (Costa 2013) and hunters (Cá 2008; Amador in press), baboons became rare and live in smaller groups or have even disappeared from some parts of the country where they were common 30 years ago. This decrease could be correlated with: (i) changes in the landscape due to extensive cashew tree (Anacardium occidentalis) plantation, which now occupies more than $70 \%$ of the whole arable land (Barry et al. 2007); (ii) intensive hunting by military groups that have consumed baboon meat in return for salary (Casanova \& Sousa 2007); (iii) bushmeat markets and restaurants that flourished in the capital and in some other smaller cities throughout the country, where baboon meat is sold and consumed along with other primate species (Casanova \& Ferreira da Silva pers. obs. 2006-2010; Cá 2008; Starin 2010; Minhós et al. under review); (iv) the use of baboon skins

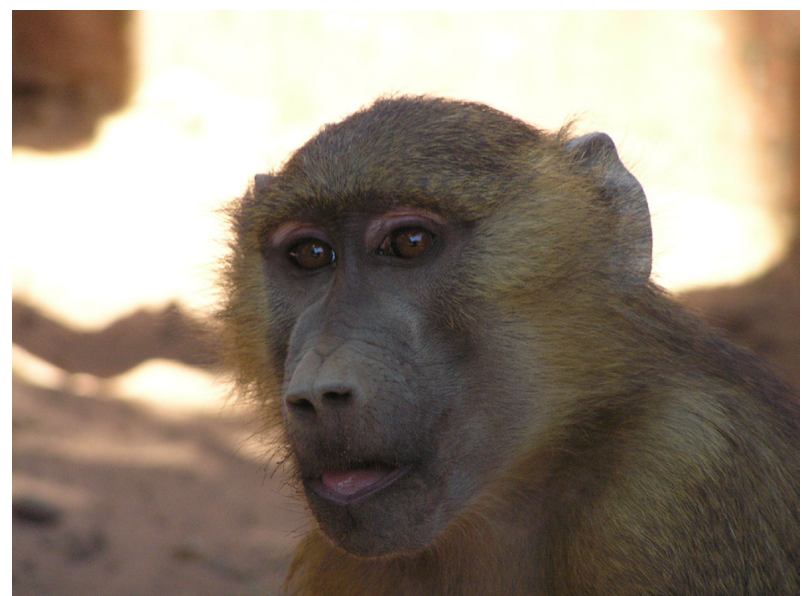

Image 1. Guinea Baboons Papio papio. Photo courtesy of A. Barata

as part of folk medicine practices (Ferreira da Silva et al. 2009; Sá et al. 2012); and (v) pet trade of very young individuals, which is a common practice throughout the country (Casanova \& Sousa 2007; Hockings \& Sousa 2011; Ferreira da Silva, pers. obs. 2006-2010). Baboons are believed to be relatively common in the southern part of the country (although patchily distributed) and absent from the northwest (Gippoliti \& Dell'Omo 2003; Casanova \& Sousa 2007; Oates et al. 2008). However, little is known about the conservation status of these persisting populations and the impact of anthropogenic related habitat modifications and hunting for pet and bushmeat trade.

One possible consequence of the rapid population decline is a reduction of genetic diversity and the isolation of sub-populations with subsequent low levels of gene flow among them, which may decrease the ability of the species to respond to future environmental changes (Frankham et al. 2002). The threats affecting baboons in Guinea-Bissau justify an assessment of the genetic diversity and degree of gene flow between persisting populations to understand their risk of extinction (Avise 2000) and to assist their future conservation and management plans.

This study describes the results of the first genetic survey on baboons in Guinea-Bissau. Sampling focussed on two of the less deforested areas (southwestern coast) within Guinea-Bissau, where baboons were reported to be present (Gippoliti \& Dell'Omo 2003; Casanova \& Sousa 2007). We aimed for a description of the genetic diversity and a preliminary assessment of the historical genetic structure of remaining populations. Moreover, we provide a comparison of our results with those obtained for Hamadryas Baboons (Hapke et al. 2001). This comparative analysis would help to understand the 


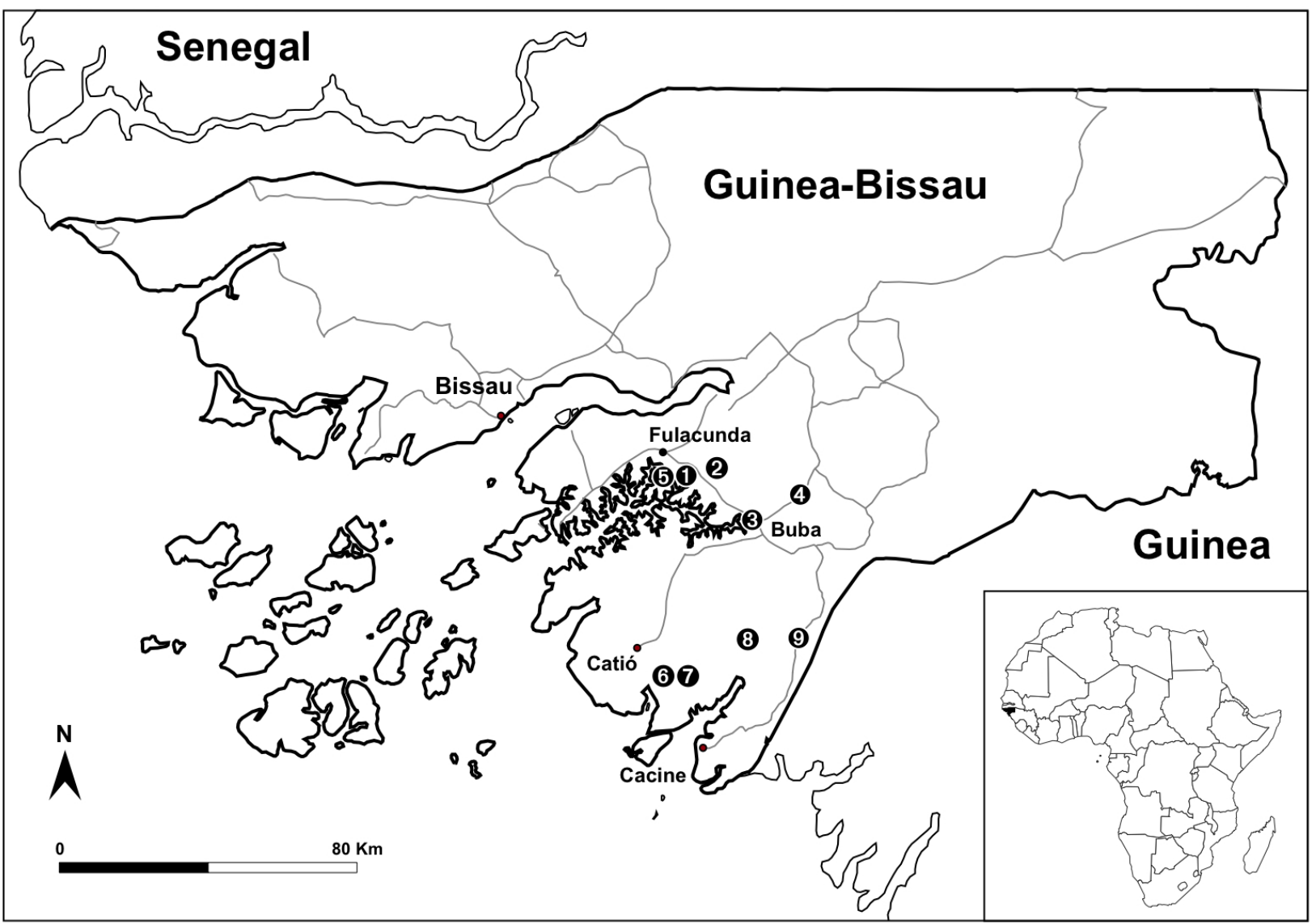

Figure 1. Location of sampling sites in Guinea-Bissau. Numbered circles refer to the sampling sites within the Cufada Lagoons Natural Park (CLNP) and Cantanhez Forest National Park (CNP) geographic regions (CLNP: from 1 to 5 and CNP: from 6 to 9 , see Table 1 for details). Bottom right: location of study area within Africa.

Table 1. Number of mtDNA sequences (N) obtained from different individuals for the geographic region of Cufada Lagoons Natural Park (CLNP) and Cantanhez Forest National Park (CNP). Samples were collected in 9 sites (see correspondence with location on Figure 1). Two social units $\left({ }^{\mathrm{SU}}\right)$ were sampled. Number of amplified and sequenced samples $(\mathrm{N})$, sample type and haplotypes (and respective frequency) are indicated for each site. * denotes samples collected from captive animals.

\begin{tabular}{|c|c|c|c|c|}
\hline $\begin{array}{l}\text { Regions } \\
\text { (N) }\end{array}$ & Sampling sites & $\mathbf{N}$ & Sample type & Haplotypes (frequency) \\
\hline \multirow{3}{*}{ CLNP } & 1. Mato de Bubatchingue ${ }^{\mathrm{su}}$ & 7 & Faecal & h1 (3) h2 (1); h3 (2); h4 (1) \\
\hline & 2. Lagoa da Cantanha & 1 & Faecal & h1 (1) \\
\hline & 3. Buba & 2 & Hair* and Faecal* & h1 (1); h5 (1) \\
\hline \multirow[t]{2}{*}{ (12) } & 4. Boyol & 1 & Hair* & h1 (1) \\
\hline & 5. Cantanha & 1 & Blood & h1 (1) \\
\hline \multirow{2}{*}{ CNP } & 6. RM & 3 & Faecal & h1(1); h6 (2) \\
\hline & 7. Caiquene $\mathrm{su}^{\mathrm{su}}$ & 7 & Faecal & h1 (1); h4 (3); h6 (1); h7 (2) \\
\hline \multirow{2}{*}{ (13) } & 8. Ponta do Rio & 2 & Faecal & h6 (1); h8 (1) \\
\hline & 9. Guilege & 1 & Hair* & h1 (1) \\
\hline
\end{tabular}

degree of genetic diversity of the Guinea-Bissau Baboon at the genus level. Our ultimate goal was to provide baseline data for future conservation genetic studies in Guinea-Bissau Baboons. 


\section{METHODS}

\section{Sample collection and preservation}

A non-invasive genetic sampling strategy was implemented as the capture of animals for collection of biological samples was considered unethical, logistically impracticable and a peril to the animal's health (Piggott \& Taylor 2003). Samples were collected in the southwestern region of the Republic of GuineaBissau during 25 days along in the dry season (January and February 2006). Sampling was concentrated in two geographically distinct locations, $60 \mathrm{~km}$ apart: (1) administrative region of Quinara $\left(11^{0} 34^{\prime}-11^{0} 51^{\prime} \mathrm{N}\right.$ \& $\left.14^{0} 49^{\prime}-15^{0} 16^{\prime} \mathrm{W}\right)$, most frequently in Cufada Lagoons Natural Park (Parque Natural das Lagoas da Cufada) (CLNP) and in (2) administrative region of Tombali $\left(11^{\circ} 20^{\prime}-11^{\circ} 05^{\prime} \mathrm{N} \& 1^{\circ} 06^{\prime}-14^{\circ} 4^{\prime} \mathrm{W}\right)$, predominantly in Cantanhez Forest National Park (Parque Nacional das Florestas de Cantanhez) (CNP) (Fig. 1 and Table 1 for sampling details). As no previous information was available on the location of social units in the sampling areas, we located individuals by detecting vocalizations, footprints and/or scats and used information from local people, guards and park guides. The GPS position for each sample was registered.

In 25 days of fieldwork, a total of 38 faecal samples (17 and 21 samples from CLNP and CNP, respectively) were collected. Most of the samples were collected opportunistically and were spatially scattered: we collected from one to three faecal samples in nine different sampling locations (distance within regions between 16-20 km). However, we observed and sampled two social units: Mato de Bubatchingue (MB) and Caiquene (Table 1). Faecal samples were preserved by desiccation using silica beads (type II from Sigma; Wasser et al. 1997). After one month in the field samples were transferred to $99 \% \mathrm{EtOH}$ and preserved at $-20^{\circ} \mathrm{C}$ prior to DNA extraction.

We collected two hair samples from captive individuals during grooming sessions and a blood sample from the carcass of a hunted animal found in the forest (Table 1). Hair samples were preserved in $99 \% \mathrm{EtOH}$ and the blood sample was collected using an FTA card $^{\circledR}$ (Whatman International Ltd, Kent, England).

This project complied with the protocols approved by $\mathrm{CIBIO}$, Porto University, Portugal (for sampling of biological material and DNA extraction of blood and faecal samples) and by the School of Social and Political Sciences, Technical University of Lisbon, Portugal (for survey questionnaires and interviews). Permits for research and sample export were obtained from the local authorities (IBAP, Institute for the Biodiversity and Protected Areas and DGFC, Direcção Geral das Florestas e Fauna) and research adhered to the legal requirements of the respective countries in which research was conducted.

\section{DNA extraction and PCR amplification}

Total genomic DNA was extracted from the outside surface of each faecal sample using guanidine-silica solution (Gerloff 1995) followed by DNA purification through microcon YM-30 columns (Millipore Iberica S.A.U., Madrid, Spain). DNA from hair samples was extracted using standard salting-out extraction protocols. DNA preserved in FTA card $^{\circledR}$ (Whatman International Ltd) was extracted according to the instructions given by the manufacturer. Non-invasive samples were processed in a laboratory dedicated to low-quality DNA samples at the research centre CIBIO (Research Center in Biodiversity and Genetic Resources). Negative controls were always included to monitor for cross-contamination.

A 391 base pair (bp) fragment of the hypervariable region 1 (HVRI) of the mtDNA (D-loop) region was PCR amplified using primers from Hapke et al. (2001). This genetic marker was selected because it: (i) is suitable to provide an overview of the intraspecific mitochondrial genetic diversity (Wan et al. 2004); (ii) allows for a higher amplification rate on non-invasive DNA samples, when compared with nuclear DNA markers (Waits \& Paetkau 2005); and (iii) made possible a comparison of our results with those obtained for Hamadryas Baboons (Hapke et al. 2001), one of the few available databases of D-loop sequences for any baboon wild population.

The PCR mixture contained $0.5 \mu \mathrm{M}$ of each primer, $4 \mu \mathrm{M}$ of each dNTP, 3\% DMSO, 1X PCR reaction buffer (with $1.9 \mathrm{mM} \mathrm{MgCl}_{2}$ ) $1 \mathrm{U}$ of Phusion ${ }^{\mathrm{TM}}$ High-Fidelity DNA Polymerase (Finnzymes, Vantaa, Finland) and $2 \mu \mathrm{l}$ of DNA template in a total volume of $10 \mu \mathrm{l}$. Amplifications were performed using a touchdown PCR protocol with an initial denaturation step at $98^{\circ} \mathrm{C}$ for $30 \mathrm{sec}$. This was followed by 10 cycles of $10 \mathrm{sec}$ at $98^{\circ} \mathrm{C}, 30 \mathrm{sec}$ at $58^{\circ} \mathrm{C}$ and $15 \mathrm{sec}$ at $72^{\circ} \mathrm{C}$, with the annealing temperature decreasing by $0.5^{\circ} \mathrm{C}$ each cycle, plus 30 cycles of $10 \mathrm{sec}$ at $98^{\circ} \mathrm{C}, 30 \mathrm{sec}$ at $53^{\circ} \mathrm{C}$ and $15 \mathrm{sec}$ at $72^{\circ} \mathrm{C}$, with a final 5 min extension at $72^{\circ} \mathrm{C}$. To monitor for contaminations, all PCR reactions included a negative and a positive PCR control, as well as the negative control from the DNA extraction. The amplicons were sequenced using the BigDye Terminator v3.1 cycle sequencing kit (Applied Biosystems, California, USA) on an ABI 3130xL Genetic Analyser (16 capillary sequencer, Applied Biosystems). Samples that exhibited the same mtDNA haplotype 
in each location were genotyped for three human microsatellite loci (D10S611, D7S503 and D5S1457) known to be polymorphic in baboons (Bayes et al. 2000) to test for possible repeated sampling of individuals.

We used a molecular protocol to identify the sex of individuals (described in Ferreira da Silva 2007) and screened 22 faecal samples across five PCR replicates.

\section{Data analysis}

Sequences were manually checked for accuracy and aligned in BIOEDIT 7.0.9 (Hall 1999). Genetic diversity indices were calculated for the entire sequence set and for the sequences obtained from the defined social units (MB and Caiquene) using ARLEQUIN 3.5 (Excoffier \& Lischer 2010). The number of variable sites, the number of pairwise differences between pairs of sequences, haplotype diversity (Hd; Nei 1987) and nucleotide diversity $(\pi$; Nei 1987) and their respective variances were calculated for the entire sequence set.

Genetic relationships among haplotypes were described by a median-joining network constructed using NETWORK 4.2.0.1 (Bandelt et al. 1999; www. fluxus-engineering.com). For this analysis, indels were included and all sites were treated with equal weights. Two sequences available at GenBank were included in the alignment for reference, one from $P$. hamadryas and the other from P. papio (Accession numbers AF275457 and AF275383, respectively).

Analysis of genetic structure was performed only with sequences from the two social units ( $M B$ and Caiquene, $\mathrm{N}=14$ ). This option prevented a possible bias in the results of genetic differentiation caused by the admixture of several social units within each geographic region. However, since some individuals of these social groups were possibly not sampled, the number of haplotypes found in each social group can be underestimated. We performed an Analysis of Molecular Variance (AMOVA analysis, Excoffier et al. 1992) using ARLEQUIN 3.5 (Excoffier et al. 2010) to assess the extent of differentiation among populations (calculating $\phi_{\mathrm{ST}}$ $\phi_{\mathrm{CT}}$ and $\phi_{\mathrm{SC}}$ ) following a non-parametric permutation approach (10,0172 permutations).

The final dataset in our study was compared to results obtained from Hamadryas Baboons (Hapke et al. 2001). Since genetic diversity within social groups can be influenced by the dispersal rate (Rogers 2000), we selected pairs of Hamadryas social groups or demes located at a similar distance to that between the two social groups sampled for Guinea Baboons (i.e., $\mathrm{N}=18$ pairs of "troops", located between $50-100 \mathrm{~km}$ ). It is assumed that the ability to disperse (i.e., the organism's movement from the natal area to the breeding area) over such a distance is the same for both species. The pairs of selected demes from Hapke et al. (2001) were as follow: Furrus-Abdur, Furrus-Dogali, Furrus-Debresina, FurrosGeleb, Furros-Molki, Durfo-Abdur, Durfo-Dogali, DurfoMolki, Durfo-Barka River, Arborobo-Abdur, ArboroboGeleb, Arborobo-Molki, Abdur-Dogali, Dogali-Kubkub, Debresina-Molki, Debresina-KubKub, Geleb-Kubkub and Molki-Barka River. D-loop sequences were downloaded from GenBank (Accession Numbers AF275383 to AF275475) and haplotype and nucleotide diversity per site and the theta $(\theta)$ were calculated for each selected pair using DNASP 4.10 .9 (Rozas et al. 2003). Finally, these

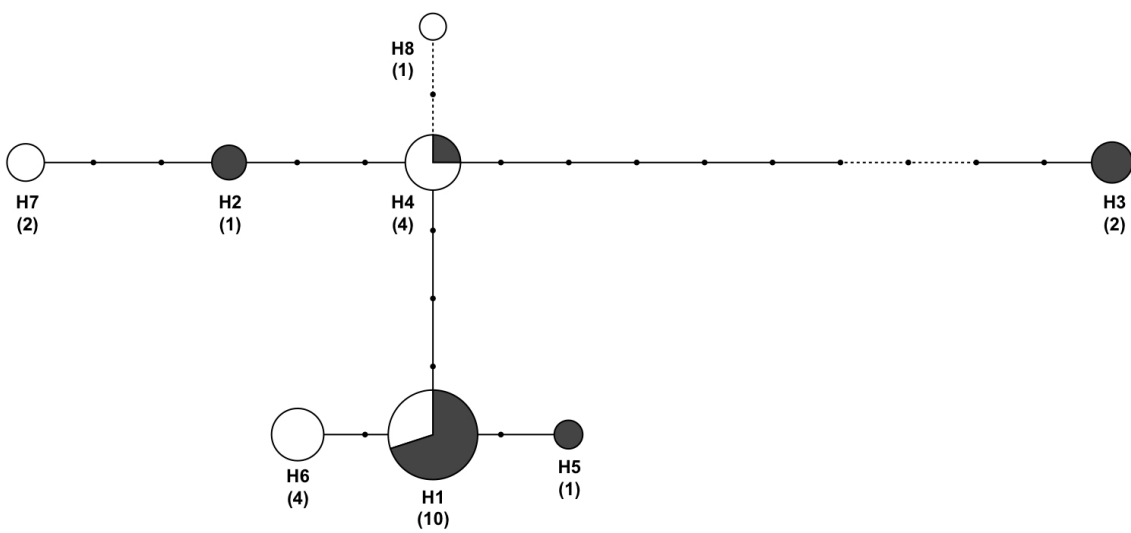

Figure 2. Median-joining network showing relationships between haplotypes (constructed using NETWORK 4.2.0.1). The Haplotypes are represented by circles with sizes proportional to respective frequency and absolute frequencies are indicated by number in parentheses. The mutation steps between the haplotypes are represented by small black dots along the lines. The branch lengths are proportional to the number of mutational steps separating haplotypes. All sites were treated with equal weights. Indels were included in the network analysis (and are represented by dashed lines). Note that if indels were not taken into account, haplotype h8 would be identical to haplotype h4 and haplotype $\mathrm{h} 3$ would be separated by one less mutation step from h4. The proportion of haplotypes found in both regions are indicated by different colours: black for Cufada Lagoons Natural Park (CLNP) and white for Cantanhez Forest National Park (CNP). 
values were compared to the results from our study.

\section{RESULTS}

\section{DNA extraction and amplification}

Extraction of DNA was attempted from all samples collected. We successfully amplified 31 of the collected faecal samples (82\%), the two hair samples and the blood sample for the $391 \mathrm{bp}$ fragment of the mtDNA D-loop. Despite the high amplification rate achieved for faecal samples, good quality sequences were only obtained for 26 out of the 31 amplicons. Two samples in Mato de Bubatchingue and two samples in RM exhibited the same haplotype and the same genotype for the three microsatellite loci. We removed from the dataset one sample per location to prevent repetition of individuals. Using the sex identification protocol, only 14/22 faecal samples gave consistently the same result three times. We effectively distinguished six females and eight males among our faecal samples of Guinea Baboons.

\section{D-loop diversity of coastal Guinea Baboons}

Sequencing of 391bp of the mtDNA D-loop region distinguished eight haplotypes from the 25 sampled individuals $(\mathrm{Hd}=0.803 \pm 0.061)$. Eighteen out of 391 nucleotide sites analyzed were polymorphic and estimated nucleotide diversity $(\pi)$ was $0.0104 \pm 0.0059$. Sixteen of the sites showed substitutions, with transitions exceeding the number of transversions (15:2). Additionally, two indels were observed: the deletion of one nucleotide in two sequences and the insertion of one nucleotide in one sequence. The mean number of pairwise differences between haplotypes (indels taken into account) was $4.06 \pm 2.1$.

The median-joining network built with the eight haplotypes displays two most common haplotypes (h1 and h4), which differ by three positions and are shared by both CLNP and CNP geographical regions but in different frequencies (h1: $28 \%$ and $12 \%$, and h4: $4 \%$ and $12 \%$ in CLNP and CNP, respectively) (Fig. 2). Five other haplotypes were found in lower frequencies (h2, h5, h6 h7 and h8) and are separated by one or two mutational steps from each other and from $\mathrm{h} 1$ and $\mathrm{h} 4$. The haplotype h8 is separated by an indel (nucleotide insertion) from the haplotype h4. An additional haplotype (h3) was observed in the CLNP sample. This haplotype h3 is separated from h4 by eight substitutions and one indel (nucleotide deletion), which corresponds to a genetic divergence of $2.3 \%$ from the central haplotype h4. Both geographic regions exhibited unique haplotypes (h2, h3
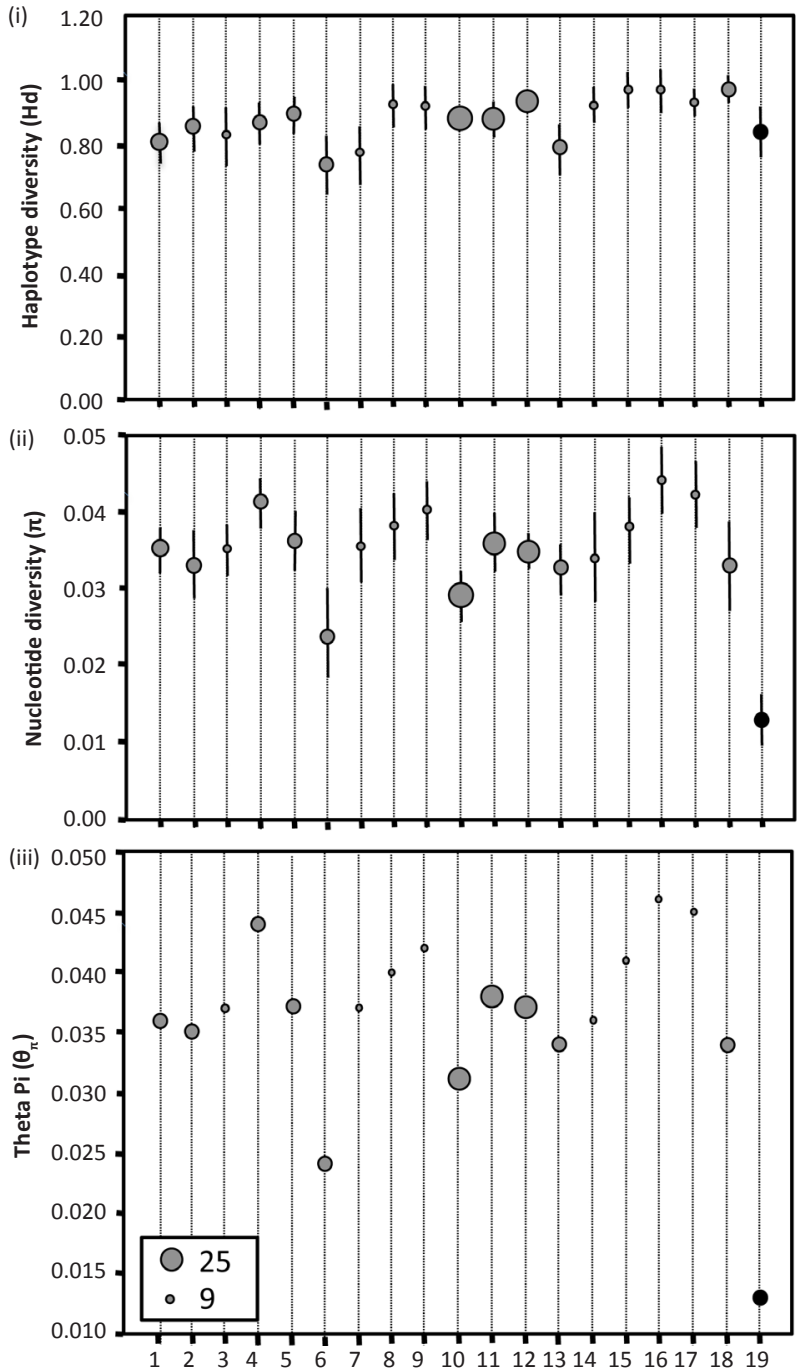

Figure 3. Comparison of genetic diversity indices between Hamadryas and Guinea Baboons. The X-axis represents pairs of demes (social units) which were separated by 50 to $100 \mathrm{~km}$.

(i) Haplotype diversity \pm standard deviation; (ii) Nucleotide diversity \pm standard deviation; (iii) Theta $\mathrm{Pi}\left(\theta_{\pi}\right)$. Grey symbols correspond to hamadryas baboons and black symbols to Guinea baboons. The sizes of the circles are proportional to the sampling effort (the circles area representing 25 sequences and 9 sequences are showed for reference). 1 - Furrus-Abdur, 2 - Furrus-Dogali, 3 - Furrus-Debresina, 4 - Furros-Geleb, 5 - Furros-Molki, 6 - Durfo-Abdur, 7 - DurfoDogali, 8 - Durfo-Molki, 9 - Durfo-Barka River, 10 - Arborobo-Abdur, 11 - Arborobo-Geleb, 12 - Arborobo-Molki, 13 - Abdur-Dogali, 14 - Dogali-Kubkub, 15 - Debresina-Molki, 16 - Debresina-KubKub, 17 Geleb-Kubkub, 18 - Molki-Barka River, 19 - MB-Caiquene

and h5 for CLNP and h6, h7 and h8 for CNP; Fig. 2).

\section{Genetic diversity and differentiation of social units}

The two social units showed the same haplotype diversity $(\mathrm{Hd}=0.810 \pm 0.130)$ and both displayed the same number of haplotypes ( $n=4$ ) (Table 1 ). The MB sample had slightly higher nucleotide diversity $\left(\pi_{\mathrm{MB}}=0.0157 \pm 0.0035\right)$ 
than the Caiquene sample $\left(\pi_{\text {Caiquene }}=0.00928 \pm 0.0021\right)$. The two social groups were tested for statistically significant genetic structure using an AMOVA analysis, which showed no phylogeographic structure of haplotypes: $7.75 \%$ of the total variance was found between social groups whereas most of the variance (92.25\%) was present within social groups. Accordingly, the fixation index estimated between Guinea Baboon social groups was low (Fst= 0.078 ) and did not differ significantly from zero $(p=0.2)$.

\section{Comparison of mitochondrial variation between Hamadryas and Guinea Baboons}

The number of haplotypes found in this study was, on average, similar to the number found in different demes of $P$. hamadryas $\left(\mathrm{Nh}_{\mathrm{HAM}}=6\right.$ and $\left.\mathrm{Nh}_{\mathrm{GUI}}=8\right)$ with similar average sampling efforts $\left(\mathrm{Nseq}_{\text {HAM }}=14\right.$ and $\mathrm{Nseq}_{\mathrm{GUI}}=14.89$ ). Nevertheless, all three other genetic measures were lower for Guinea Baboons social units, as documented for haplotype diversity (average $\mathrm{Hd}_{\text {HAM }}=0.886$ and $\mathrm{Hd}_{\mathrm{GUI}}=0.846$, Fig. 3i), average nucleotide diversity found per site $\left(\pi_{\mathrm{HAM}=} 0.0356\right.$ and $\pi_{\mathrm{GUI}}=0.01297$, Fig. 3ii) and Theta based on $\pi\left(\theta \pi_{\text {HAM }}=0.037 \pm 0.0053\right.$ and $\theta \pi_{\mathrm{GUI}}=0.013$, Fig. 3iii), suggesting lower effective population size for Guinea Baboons.

\section{DISCUSSION}

The present work estimated for the first time the mitochondrial genetic diversity levels for wild Guinea Baboons in Guinea-Bissau and presented an assessment of the historical genetic structure of two populations.

Genetic diversity of baboons in Guinea Bissau $\left(\mathrm{Hd}_{\mathrm{GUI}}=0.803 \pm 0.061 ; \pi_{\mathrm{GUI}}=0.0104 \pm 0.0059\right)$, according to Grant \& Bowen (1998), may be interpreted as a result of a large and stable population over a long period of time or as the occurrence of a secondary contact zone between previously differentiated lineages $(\mathrm{Hd}>0.5$ and $\pi>0.5 \%$, Grant \& Bowen 1998). In particular, the presence of a very distinctive haplotype (h3) harboured by two individuals in a homogenous deme (social unit Mato de Bubatchingue) suggests that the hypothesis of a contact zone between two genetically divergent populations in CNLP (Avise et al. 1987) best explains the observed results. Alternatively, past or contemporary dispersal from other populations can explain the presence of $h 3$.

Although the amplification of nuclear pseudogenes can be common in studies of primates using mtDNA as a molecular marker (Mourier et al. 2001; Thalmann et al. 2004), we excluded the possibility that h3 was a numt.
Throughout our study and in particular in the samples harbouring h3 (extracted from faecal samples), we did not see ghost bands in agarose gels when testing for DNA amplification or double peaks in chromatograms (Bensasson et al. 2001). Moreover, sequences did not show any ambiguities, either when comparing both sequence strands or when comparing polymorphic sites between sequences in the final alignment (Bensasson et al. 2001). We also believe that obtaining no sequencing product for some amplicons was related to low DNA quality/quantity and not with mutations at the flanking regions, as Hapke et al. (2001) designed primers in highly conserved regions.

No evidence was found for significant geographic structure of haplotypes, and we propose that baboons present in this area of Guinea-Bissau do not represent two genetically differentiated populations. This result suggests a common origin of CNP and CLNP populations or dispersal of individuals between the two sampling locations. Guinea Baboons are able to move about $40 \mathrm{~km}$ a day (Galat-Luong pers. comm. January 2007), which almost equals the distance between the two sampling sites in Guinea-Bissau (about 60km; see Fig. 1), and they occupy broad home ranges in Senegal $\left(25 \mathrm{~km}^{2}\right.$, Fickenscher 2010).

A historical female-biased dispersal pattern for the Guinea Baboon can explain the presence of very different maternal lineages in the same social unit (see results for CLNP social unit, Mato de Bubatchingue) and higher percentage of variation within social units (Di Fiore 2003). This hypothesis would contrast with the proposal of unique maternal family groups for the Senegalese population made by Sharman (1981) based on observational data but it agrees with evidences for male philopatry based in nuclear DNA data provided by Fickenscher (2010). Fickenscher (2010) found significantly higher Fst values and a higher negative correlation between pairwise relatedness and geographic distances for males when compared with females, which imply a scenario of female-biased dispersal (Fickenscher 2010). Furthermore, in Papio male-biased dispersal species (e.g., Gray-footed Baboons, Burrell 2008) it is common to observe the inverse pattern of D-loop mtDNA variance found for the Guinea Baboon (i.e., greater percentage of variance between social units than within) and significant values of Fst between social units (e.g., Fst gra $=0.757$, Burrell 2008).

Moreover, it was found (Ferreira da Silva et al. unpublished data) that the haplotype networks of Guinea and Hamadryas Baboon social units display a similar structure: two divergent groups were present in 
most Hamadryas Baboon groups, which resembles the haplotype structure found in Guinea Baboons social units by this study, although with a much lower degree of differentiation between the two most frequent haplotypes (h1 and h4). Hamadryas Baboons' display a pattern of female-biased dispersal (Hapke et al. 2001; Hammond et al. 2006; Handley et al. 2006) and the social organization of Guinea Baboons and Hamadryas Baboons share some characteristics (Galat-Loung et al. 2006; Patzelt et al. 2011). Therefore is possible that the similarity between haplotype networks of Guinea and Hamadryas Baboon social units is related with femaledispersal, although such proposition needs to be further investigated.

The current work suggests lower mitochondrial genetic diversity (both nucleotide diversity and $\theta \pi$ ) for Guinea-Bissau Baboons when compared with Hamadryas Baboons. Additionally, the mean number of pairwise differences estimated for Guinea Baboons (4.06, range 12-1) is rather low when compared with those observed in Hamadryas Baboons (12.40, range 23-1; Hapke et al. 2001). Moreover, comparing our results $\left(\pi_{\mathrm{GUI}}=0.0104 \pm 0.0059\right)$ with Kinda, Yellow and Gray-footed Baboons mtDNA genetic diversity estimates $\left(\pi_{\mathrm{KIN}}=0.036, \pi_{\mathrm{YEL}}=0.086\right.$ and $\pi_{\mathrm{GRA}}=0.053$, Burrell 2008), the pattern of lower nucleotide diversity for Guinea-Bissau Baboons is still noticeable. Reasons that could explain such differences on genetic diversity levels include: (i) a strong stochastic event that would affect the D-loop region, as a selective sweep (Galtier et al. 2000); (ii) a past population bottleneck, which would result in a decrease in nucleotide diversity, followed by a population expansion early enough to generate the same number of haplotypes but not large differences among them (Grant \& Bowen 1998); or (iii) a founder effect, which could be a consequence of a rapid colonisation of western Africa by this species (Zinner et al. 2011) or re-colonisation events by few or genetically similar individuals.

Disentangling among the hypotheses posed by this initial genetic survey will be a future challenge. With the use of more variable molecular markers (e.g., microsatellites, Wan et al. 2004) it will be possible to obtain a broader idea of genetic diversity patterns at different genome compartments and to perform studies on the demographic history of baboons in Guinea-Bissau. Additionally, if confirmed the presence of baboons in other areas within the country (e.g., Boé sector, in the southern part, see Casanova \& Sousa 2007), the inclusion of samples from a wider area would allow the assessment of the degree of functional connectivity between all persisting populations. Despite the above- mentioned limitations, our study is the first approach to estimate genetic diversity of baboons in Guinea-Bissau and one of the very few comparing mtDNA patterns of different species of Papio.

\section{REFERENCES}

Amador, R., (in press). Perceptions and atitudes of the Beafada and the Balanta towards biodiversity in the CLNP, Guinea-Bissau, West Africa". PhD Thesis. Department of Anthropology, School of Social and Political Sciences, Technical University of Lisbon.

Avise, J.C. (2000). Phylogeography: The History and Formation of Species. Harvard University Press, Cambridge, MA, viii+447pp.

Avise, J.C., J. Arnold, R.M. Ball, E. Bermingham, T. Lamb, J. Neigel, C. Reeb \& N. Saunders (1987). Intraspecific phylogeography: the mitochondrial bridge between population genetics and systematics. Annual Review of Ecology, Evolution, and Systematics 18: 489-522.

Barry, B., E.G.E. Creppy \& Q. Wodon (2007). Cashew production, taxation, and poverty in Guinea-Bissau. In: MPRA Paper 11181, University Library of Munich, Germany. <http://ideas.repec.org/p/ pra/mprapa/11181.html> Downloaded on 12 October 2012.

Bandelt, H-J. \& P. Forster, A. Röhl (1999). Median-joining networks for inferring intraspecific phylogenies. Molecular Biology and Evolution 16(1): 37-48.

Bayes, M., K. Smith, S. Alberts, J. Altmann \& M.W. Bruford (2000). Testing the reliability of microsatellite typing from faecal DNA in the savannah baboon. Conservation Genetics 1: 173-176.

Bensasson, D., D.X. Zhang, D.L. Hartl \& G.M. Hewitt (2001). Mitochondrial pseudogenes: evolution's misplaced witnesses. Trends in Ecology and Evolution 16: 314-321; http://dx.doi. org/10.1016/S0169-5347(01)02151-6

Burrell, A.S. (2008). Phylogenetics and population genetics of central African baboons. PhD Thesis. Department of Anthropology, New York University, 308pp.

Cá, A. (2008). Estudos Sobre Caça e Mercado de Primatas em Tombali, Sul da Guiné-Bissau. Master Thesis. Instituto de Ciências Biológicas, Universidade Federal de Minas Gerais, 80pp.

Casanova, C. \& C. Sousa (2007). National action plan for the conservation of the Chimpanzee, Red Western Colobus and Black and White Western Colobus monkey populations in Guinea-Bissau Republic. Instituto da Biodiversidade e das Áreas Protegidas (IBAP), Bissau, Guinea-Bissau, 94pp.

Costa, S. (2010). Social Perceptions of Nonhumans in Tombali (Guinea Bissau, West Africa): a contribution to Chimpanzee (Pan troglodytes verus) conservation. PhD Thesis. Department of Psychology, University of Stirling, 206pp.

Costa, S., C. Casanova, C. Sousa \& P. Lee (2013). The good, the bad and the ugly: perceptions of wildlife in Tombali (Guinea-Bissau, West Africa). Journal of Primatology : 2(1): 1-7; http://dx.doi. org/10.4172/2167-6801.1000110.

Di Fiore, A. (2003). Molecular genetic approach to the study of primate behaviour, social organization and reproduction. Yearbook Physical Anthropology 46: 62-99; http://dx.doi.org/10.1002/ajpa.10382

Excoffier, L., P.E. Smouse \& J.M. Quattro (1992). Analysis of molecular variance inferred from metric distances among DNA haplotypes: application to human mitochondrial DNA restriction data. Genetics 131: 479-491

Excoffier, L. \& H.E.L. Lischer (2010). Arlequin suite ver 3.5: a new series of programs to perform population genetics analyses under Linux and Windows. Molecular Ecology Resources 10: 564-567; http:// dx.doi.org/10.1111/j.1755-0998.2010.02847.x

Ferreira da Silva, M.J. (2007). Mitochondrial Diversity in Guinea Baboons (Papio hamadryas papio): a non-invasive study in the coastal area of Guinea-Bissau. Master Thesis. CIBIO (Centro de Investigação em Biodiversidade e Recursos Genéticos), Porto 
University, 72pp.

Ferreira da Silva, M.J., R. Sá, T. Minhós, F. Sousa, R. Godinho, L. Vicente, C. Sousa, C. Casanova \& M.W. Bruford (2009). Evidence of non-human primate skin commerce for traditional practices in Guinea Bissau (West Africa). Folia Primatologica 80: 394-425.

Fickenscher, G. (2010). Genetic population structure of free-ranging Guinea Baboons (Papio papio) in the Niokolo-Koba National Park, Senegal. Master Thesis. German Primate Center, University of Gottingen, 82pp.

Frankham, R., D.A. Briscoe \& J.D. Ballou (2002). Introduction to Conservation Genetics. Cambridge University Press, New York, $617 p p$.

Galat-Luong, A., G. Galat \& S. Hagell (2006). The social and ecological flexibility of Guinea Baboons: Implications for Guinea Baboon social organization and male strategies, pp. 105-121. In: Swedell, L. \& S.R. Leigh (eds.). Reproduction and Fitness in Baboons: Behavioral Ecological and Life History Perspectives Part I. Springer, New York, 322pp.

Galat, G., A. Galat-Luong \& Y. Keita (1999-2000). Régression de la distribuition et statut actuel du babouin Papio papio en limite d'aire de repartition au Senegal. African Primates 4(1\&2): 69-70.

Galtier, N., F. Depaulis \& N.H. Barton (2000). Detecting bottlenecks and selective sweeps from DNA sequence polymorphism. Genetics 155: 981-987.

Gerloff, U., C. Schlötterer, K. Rassmann, I. Rambold, G. Hohmann, B. Fruth \& D. Tautz (1995). Amplification of hypervariable simple sequence repeats (microsatellites) from excremental DNA of wild living bonobos (Pan paniscus). Molecular Ecology 4(4): 515-518; http://dx.doi.org/10.1111/j.1365-294X.1995.tb00247.x

Gippoliti, S. \& G. Dell'Omo (2003). Primates of Guinea-Bissau, West Africa: distribution and conservation status. Primates Conservation 19: 73-77.

Grant, W.S. \& B.W. Bowen (1998). Shallow population histories in deep evolutionary lineages of marine fishes: insights from sardines and anchovies and lessons for conservation. Journal Hereditary 89 415-426.

Hall, T.A. (1999). BioEdit: a user-friendly biological sequence alignment editor and analysis program for Windows 95/98/NT. Nucleic Acids Symposium Series 41: 95-98.

Handley, L.J.L., R.L. Hammond, G. Emaresi, A. Reber \& N. Perrin (2006). Low Y chromosome variation in Saudi-Arabian hamadryas Baboons (Papio hamadryas hamadryas). Heredity 96: 298-303; http://dx.doi.org/10.1038/sj.hdy.6800803

Hapke, A., D. Zinner \& H. Zischle (2001). Mitochondrial DNA variation in Eritrean Hamadryas baboons (Papio hamadryas hamadryas): life history influences population genetic structure. Behavioural Ecology Sociobiology 50: 483-492; http://dx.doi.org/10.1007/ s002650100393

Hammond, R.L., L.J.L. Handley, B.J. Winney, M.W. Bruford \& N. Perrin (2006). Genetic evidence for female-biased dispersal and gene flow in a polygynous primate. Proceedings Royal Society B 273: 479-484; http://dx.doi.org/10.1098/rspb.2005.3257

Hockings, K.J. \& C. Sousa (2011). Human-Chimpanzee Sympatry and Interactions in Cantanhez National Park, Guinea-Bissau: Current Research and Future Directions. Primate Conservation 26; http:// dx.doi.org/10.1896/052.026.0104

IUCN (2013). IUCN Red List of Threatened Species. assessed by Oates J.F., S. Gippoliti \& C. P. Groves (2008). Papio papio. Version 2012.1. <www.iucnredlist.org>. Downloaded on 12 October 2012.
Minhós, T., E. Wallace, M.J.F. da Silva, R. Sá, M. Carmo, A. Barata, M.W. Bruford (under review). DNA Identification of primate bushmeat from urban markets in Guinea-Bissau and its implications for conservation.

Mourier, T., A.J. Hansen, E. Willerslev \& P. Arctander (2001). The Human Genome Project reveals a continuous transfer of large mitochondrial fragments to the nucleus. Molecular Biology and Evolution 18: 1833-1837.

Nei, M. (1987). Molecular Evolutionary Genetics. Columbia University, New York, $\mathrm{x}+512 \mathrm{pp}$.

Oates, J.F., S. Gippoliti \& C.P. Groves (2008). Papio papio. In: IUCN 2012. IUCN Red List of Threatened Species. Version 2012.1. <www. iucnredlist.org>. Downloaded on 12 October 2012.

Piggott, M.P. \& A.C. Taylor (2003). Remote collection of animal DNA and its applications in conservation management and understanding the population biology of rare and cryptic species. Wildlife Research 30: 1-13; http://dx.doi.org/10.1071/WR02077

Patzelt, A., D. Zinner, G. Fickenscher, S. Diedhiou, B. Camara, D. Stahl \& J. Fischer (2011). Group composition of Guinea Baboons (Papio papio) at a water place suggests a fluid social organization. International Journal Primatology 32: 652-668; http://dx.doi. org/10.1007/s10764-011-9493-z

Rogers, J. (2000). Molecular genetic variation and population structure in Papio Baboons, pp. 57-75. In: Whitehead, P.F. \& C.J. Jolly (eds.). Old World Monkeys. Cambridge University Press, United Kingdom, 528pp.

Rozas, J., J.C. Sanchez-DelBarrio, X. Messeguer \& R. Rozas (2003). DNAsp - DNA polymorphism analysis by the coalescent and other methods. Bioinformatics 19(18): 2496-2497; http://dx.doi. org/10.1093/bioinformatics/btg359

Sá, R., M.J.F. da Silva, F. Sousa \& T. Minhós (2012). The trade and ethnobiological use of Chimpanzee body parts in Guinea-Bissau: implications for conservation. Traffic Bulletin 24(1): 31-34.

Sharman, M.J. (1981). Feeding, ranging and social organisation of the Guinea baboon. PhD Thesis. Department of Psychology, University of St. Andrews. 214pp.

Starin, E.D. (1989). Threats to the monkeys of The Gambia. Oryx 23(4): 208-214; http://dx.doi.org/10.1017/S0030605300023048

Starin, E.D. (2010). How corruption and deforestation fuel horrific trade in west-African primates. Wildlife Trade 16: 1-4.

Thalmann, O., J.H. Hebler, N. Poinar, S. Pääbo \& L. Vigilant (2004). Unreliable mtDNA data due to nuclear insertions: a cautionary tale from analysis of humans and other great apes. Molecular Ecology 13: 321-335; http://dx.doi.org/10.1046/j.1365-294X.2003.02070.x

Wan, Q.H., H. Wu, T. Fujihara \& S. Fang (2004). Which genetic marker for which conservation genetics issue? Electrophoresis 25: 21652176; http://dx.doi.org/10.1002/elps.200305922

Wasser, S.K., C.S. Houston, G.M. Koehler, G.G. Cadd \& S.R. Fain (1997). Techniques for application of faecal DNA methods to field studies of Ursids. Molecular Ecology 6: 1091-1097; http://dx.doi. org/10.1046/j.1365-294X.1997.00281.x

Wolfheim, J.H. (1983). Primates of the World: Distribution, Abundance and Conservation. University of Washington Press, London, 832pp.

Zinner, D., U. Buba, S. Nash \& C. Roos (2011). Pan-African Voyagers: The Phylogeography of Baboons. pp. 267-306. In: Sommer V. \& C. Ross (eds.) Primates of Gashaka. Socio-ecology and Conservation in Nigeria's Biodiversity Hotspot. Series: Developments in Primatology: Progress and Prospects. Vol.-35. Springer, London, xviii+534pp. 
Portuguese Abstract: À semelhança de outras espécies de primatas da África Ocidental, a perda de habitat e a caça intensiva ameaçam o Babuíno da Guiné (Papio papio), um primata raramente estudado no passado. Estes factores de ameaça contribuíram para uma redução populacional significativa nos últimos 30 anos. O nosso estudo apresenta estimativas de diversidade genética para o Babuíno da Guiné que foram baseadas num fragmento de 391 pares de bases do DNA mitocondrial, da região hipervariável I do D-loop. Foram usadas amostras não-invasivas recolhidas em duas regiões da Guiné-Bissau: - Parque Natural das Lagoas da Cufada e o Parque Nacional das Florestas de Cantanhez. Embora a amostragem tenha sido de natureza oportunística, foram observados e amostrados dois demes (grupos sociais). A análise das 25 sequências obtidas revelou sete haplótipos geneticamente próximos e um haplótipo muito diferenciado. A existência deste haplótipo muito divergente sugere uma zona de contacto entre populações geneticamente diferenciadas ou a presença de indivíduos imigrantes na Cufada. As áreas amostradas partilham dois dos haplótipos mais comuns, embora em frequências diferentes, e exibem haplótipos únicos. Entre os grupos sociais não foi encontrada diferenciação genética significativa, possivelmente devido a uma origem ancestral comum das regiões ou a dispersão frequente de babuínos. A presença de linhagens matrilineais distintas e a elevada percentagem de variação mitocondrial nos grupos sociais sugere dispersão histórica mediada por fêmeas nos Babuínos da Guiné da Guiné-Bissau. Adicionalmente, foi comparada a diversidade genética mitocondrial entre os Babuínos da Guiné e os Babuínos Hamadryas (Eritreia). Os Babuínos da Guiné apresentaram diversidade haplotípica nucleotídica e Theta Pi mais baixa do que os Babuínos Hamadryas, o que sugere diferentes histórias demográficas para as espécies comparadas. O nosso trabalho suporta a necessidade da realização de estudos genéticos adicionais usando amostras recolhidas em toda a área de ocorrência da espécie.
Acknowledgements: We gratefully acknowledge S. Camará, C. Sousa and A. Barata for assistance in fieldwork. We thank Direç̧ão Geral das Florestas e Fauna do Governo da República da Guiné-Bissau, IBAP (Instituto da Biodiversidade e Áreas Protegidas) and $\mathrm{AD}$ (Acção para o Desenvolvimento, NGO) for helping in the logistics of the study. We acknowledge ICNB - Divisão de Aplicações de Convenções/CITES (Biodiversity and Nature Conservation Portuguese Institute/ CITES convention application division) for sample transport permits to Portugal. Photo courtesy of A. Barata. We also thank G. Dantas and CTM staff for lab assistance. We acknowledge A. Beja-Pereira, I. Russo, J. Cable, J. Chen, N. Ferrand and S.J.E. Baird for helpful discussions and manuscript comments, to R. Lopes for figures design and to D. Zinner and two anonymous reviewers whose comments greatly improved this manuscript. Molecular work was supported by $\mathrm{CIBIO} / \mathrm{InBio}$. Fieldwork was sponsored by Barbosa \& Almeida Glass I - Serviços de Gestão e Investimentos, SA. and Carosi - Cápsulas e Rolhas Sintéticas Lda. APP (Portuguese Primatological Association) and DARI Project assured fieldwork logistics. R. Godinho worked under a FCT post-doc grant (SFRH/BPD/36021/2007).

Author Contribution: Ferreira da Silva was responsible for the field and laboratorial work, data analysis and writing of the manuscript. All co-authors were Ferreira da Silva master supervisors and contributed to the planning of the project and provided the important suggestions during the manuscript preparation.

Author Details: MARIA J. FerReIRA DA SILVA was a master student in CIBIO (Research Centre in Biodiversity and Genetic Resources, Porto University) and has been researching Guinea baboons in Guinea-Bissau for the last seven years. She finished her PhD degree at School of Biosciences, Cardiff University, UK in 2012 and is currently a post-doc researcher in Cardiff University and in CIBIO. CATARINA CASANOVA is an associated professor in the Department of Anthropology at the School of Social and Political Sciences (Technical University of Lisbon, Lisbon, Portugal). She completed her DPhil degree in the University of Cambridge, UK. She has being working in Guinea-Bissau for the last eight years and is specialized in biological anthropology (Primatology), ethnobiology and primate conservation.

RAQUEL GODINHO is post-doc researcher in CIBIO. She completed her PhD degree in Faculty of Sciences in Lisbon University, Portugal. She works in conservation genetics for the last six years and has in-depth experience in analyzing noninvasive biological samples of various mammal species. 